Article

\title{
Interesterification of Egg-Yolk Phosphatidylcholine with $p$-Methoxycinnamic Acid Catalyzed by Immobilized Lipase B from Candida Antarctica
}

\author{
Magdalena Rychlicka * and Anna Gliszczyńska *(D) \\ Department of Chemistry, Wrocław University of Environmental and Life Sciences, Norwida 25, \\ 50-375 Wrocław, Poland \\ * Correspondence: rychlicka.magda@wp.pl (M.R.); anna.gliszczynska@wp.pl (A.G.); \\ Tel.: +48-71-320-5183 (A.G.)
}

Received: 14 September 2020; Accepted: 5 October 2020; Published: 14 October 2020

check for updates

\begin{abstract}
The $p$-methoxycinnamic acid ( $p$-MCA) is one of the most popular phenylpropanoids, the beneficial impact of which on the human health is well documented in the literature. This compound has shown many valuable activities including anticancer, antidiabetic, and neuroand hepatoprotective. However, its practical application is limited by its low bioavailability resulting from rapid metabolism in the human body. The latest strategy, aimed at overcoming these limitations, is based on the production of more stability in systemic circulation bioconjugates with phospholipids. Therefore, the aim of this research was to develop the biotechnological method for the synthesis of phospholipid derivatives of $p$-methoxycinnamic acid, which can play a role of new nutraceuticals. We developed and optimized enzymatic interesterification of phosphatidylcholine (PC) with ethyl p-methoxycinnamate (Ep-MCA). Novozym 435 and a binary solvent system of toluene/chloroform 9:1 (v/v) were found to be the effective biocatalyst and reaction medium for the synthesis of structured $p$-MCA phospholipids, respectively. The effects of the other reaction parameters, such as substrate molar ratio, enzyme dosage, and reaction time, on the degree of incorporation of $p$-MCA into PC were evaluated by use of an experimental factorial design method. The results showed that substrate molar ratio and biocatalyst load have significant effects on the synthesis of $p$-methoxycinnamoylated phospholipids. The optimum conditions were: Reaction time of three days, $30 \%(w / w)$ of Novozym 435, and 1/10 substrate molar ratio PC/Ep-MCA. Under these parameters, $p$-methoxycinnamoylated lysophosphatidylcholine ( $p$-MCA-LPC) and $p$-methoxycinnamoylated phosphatidylcholine ( $p$-MCA-PC) were obtained in isolated yields of $32 \%$ and $3 \%(w / w)$, respectively.
\end{abstract}

Keywords: egg-yolk phosphatidylcholine; p-methoxycinnamic acid; lipase-catalyzed interesterification; Novozym 435; methoxy derivatives of phenolic acids

\section{Introduction}

Phenolic acids are gaining considerable interest to consumers and food manufacturers due to the literature reports indicating that their consumption has a great impact on the human body condition and health. It is generally well known that a diet rich in these compounds favors the prevention and reduces the risk of several degenerative diseases such as cardiovascular disease, atherosclerosis, and cancer. Among phenolic acids, especially useful properties exhibit hydroxy and methoxy derivatives of cinnamic acid. Their strong antioxidant properties are mostly determined by the presence of hydroxy substituents on the aromatic ring, while $p$-methoxy group in the structure of cinnamic acid is responsible for efficient insulin release [1-5] and enhancing cognition in an acute model of memory deficit [6-8]. Demonstrated in many published reports, less anticancer [9], antidiabetic [2], 
and neuro- [7] and hepatoprotective [1] activity of hydroxylated aromatic acids than their methoxylated forms suggests that the health-promoting effects of the latter ones do not result from their antioxidant potential. Therefore, $\mathrm{O}$-methoxylated derivatives of cinnamic acid are the subject of extensive studies aimed at evaluation of their mechanism of action and efficient delivery to the organism.

The $p$-methoxycinnamic acid ( $p$-MCA, 4-methoxycinnamic acid, 4MCA) is a phenylpropanoid that commonly occurs in food products such as coffee [10], peanuts [11], sugarcane [12], brown rice [13], rice bran, and turmeric [14]. It is also one of the most biologically active ingredient of Scrophularia buergeriana and Kaempferia galanga, herbs that have been used for centuries in Oriental medicine as natural remedies for preventing and curing many diseases and ailments like cold, fever, coughs, asthma, dyspepsia, constipation, hypertension, swelling, rheumatism, inflammatory tumors, neuritis, and depression [6,15-17]. Most studies and reported data indicate a high therapeutic potential of $p$-MCA. In Table 1, presented below, the results of in vitro and in vivo tests, which confirm the significant hepato-, neuro-, antidiabetic and chemopreventive properties of $p$-MCA, are summarized. These reports also emphasize that $\alpha, \beta$-unsaturated ester moiety and the presence of methoxy group in the para position of the benzene ring are crucial pharmacophores implying biological potential of this molecule. It is also worth noting that in some research this compound has shown higher activity than the reference compounds. Under the in vitro tests performed on rat hepatocytes with toxicity induced by carbon tetrachloride $\left(\mathrm{CCl}_{4}\right)$, it has been demonstrated that $p$-MCA shows comparable hepatoprotective activity to silybin even when it is used in several dozen times lower concentration [18]. Furthermore, this acid and its ethyl ester have been reported as effective inhibitors of $\alpha$-glucosidase, exhibiting 100-fold higher activity than 1-deoxynojirimycin used as positive control [2]. In the aspect of chemopreventive properties, $p$-MCA exhibits comparable activity to that reported for doxorubicin, with the important difference that its action was more selective towards HCT-116 cells than against normal colonic epithelial cell line (NCM460) [19].

Table 1. Biological activity of $p$-MCA and its ester.

\begin{tabular}{|c|c|c|c|c|c|}
\hline & Molecule & Research Model & Active Dose & Mechanism of Action & Ref. \\
\hline \multirow{9}{*}{$\begin{array}{l}\text { Antidiabetic } \\
\text { and hepatoprotective } \\
\text { activity }\end{array}$} & $p$-MCA & enzymes & $0.044 \pm 0.006\left(\mathrm{IC}_{50}\right)$ & $\alpha$-glucosidase inhibition & [2] \\
\hline & $p$-MCA & *STPZ-induced rats & $40 \mathrm{mg} / \mathrm{kg}$ & $\begin{array}{l}\text { insulin secretion, } \\
\text { gluconeogenesis } \\
\text { inhibition }\end{array}$ & [3] \\
\hline & $p$-MCA & INS- 1 cell line & $100 \mu \mathrm{M}$ & insulin secretion & [5] \\
\hline & $p$-MCA & Wistar rats & $5 \mathrm{mg} / \mathrm{kg}$ & insulin secretion & [5] \\
\hline & $p$-MCA & * STPZ-induced rats & $40-100 \mathrm{mg} / \mathrm{kg}$ & insulin secretion & [4] \\
\hline & $p$-MCA & INS-1 cell line & $100 \mu \mathrm{M}$ & $\begin{array}{l}\mathrm{Ca}^{2+} \text { influx, insulin } \\
\text { secretion }\end{array}$ & [20] \\
\hline & $p$-MCA & *STPZ-induced rats & $10-40 \mathrm{mg} / \mathrm{kg}$ & insulin secretion & [21] \\
\hline & $p$-MCA & $\begin{array}{l}\mathrm{CCl}_{4} \text { intoxicated } \\
\text { rat hepatocytes }\end{array}$ & $1-5 \mu \mathrm{M}$ & - & [18] \\
\hline & $p$-MCA & $\mathrm{CCl}_{4}$-intoxicated rat & $50 \mathrm{mg} / \mathrm{kg}$ & - & [1] \\
\hline \multirow{4}{*}{$\begin{array}{c}\text { Neuroprotective } \\
\text { activity }\end{array}$} & $p$-MCA & $\begin{array}{c}\text { glutamate-insulted rat } \\
\text { cortical cell }\end{array}$ & $1 \mu \mathrm{M}$ & - & [6] \\
\hline & $\mathrm{E} p-\mathrm{MCA}$ & $\begin{array}{c}\text { glutamate-insulted rat } \\
\text { cortical cell }\end{array}$ & $0.01-1 \mu \mathrm{M}$ & $\begin{array}{c}\mathrm{Ca}^{2+} \text { influx, } \\
\text { glutamatergic } \\
\text { antagonism }\end{array}$ & [7] \\
\hline & $\mathrm{E} p$-MCA & ICR-mices & $0.01-2 \mathrm{mg} / \mathrm{kg}$ & - & {$[8]$} \\
\hline & $\begin{array}{l}p \text {-MCA, } \\
\mathrm{E} p-\mathrm{MCA}\end{array}$ & $\begin{array}{l}\text { Wistar rats with } \\
\text { cognitive dysfunction }\end{array}$ & $50-100 \mathrm{mg} / \mathrm{kg}$ & - & {$[22]$} \\
\hline
\end{tabular}


Table 1. Cont.

\begin{tabular}{|c|c|c|c|c|c|}
\hline & Molecule & Research Model & Active Dose & Mechanism of Action & Ref. \\
\hline \multirow{7}{*}{$\begin{array}{c}\text { Chemopreventive } \\
\text { activity }\end{array}$} & $p$-MCA & HepG2 cell line & $\begin{array}{c}27.1 \mu \mathrm{g} / \mathrm{mL} \\
\left(\mathrm{IC}_{50}\right) \\
\end{array}$ & induction of apoptosis & [17] \\
\hline & $p$-MCA & Wistar rats & $40 \mathrm{mg} / \mathrm{kg}$ & - & [14] \\
\hline & E $p-\mathrm{MCA}$ & ** DMAB-induced mices & $\begin{array}{l}23.4 \mathrm{mg} / \mathrm{kg} \\
\text { (oil fraction) }\end{array}$ & induction of apoptosis & [23] \\
\hline & $p$-MCA & HCT-116 cell line & $\begin{array}{l}10 \mu \mathrm{M} \\
\left(\mathrm{IC}_{50}\right)\end{array}$ & induction of apoptosis & [19] \\
\hline & $\mathrm{E} p-\mathrm{MCA}$ & MCF-7 cell line & $\begin{array}{c}360 \mu \mathrm{g} / \mathrm{mL} \\
\left(\mathrm{IC}_{50}\right)\end{array}$ & - & [24] \\
\hline & Ep-MCA & HCT-116 cell line & $\begin{array}{l}42 \mu \mathrm{g} / \mathrm{mL} \\
\left(\mathrm{IC}_{50}\right)\end{array}$ & induction of apoptosis & [25] \\
\hline & E $p$-MCA & $* * * \mathrm{DMH}$-induced rats & $40 \mathrm{mg} / \mathrm{kg}$ & - & [9] \\
\hline
\end{tabular}

* Streptozotocin (STPZ)-induced diabetic rats; ${ }^{* *}$ Mice with colon cancer induced by dimethylbenz(a)anthracene (DMAB) ${ }^{* * *}$ Rats with colon cancer induced by dimethylhydrazine (DMH); INS-1, rats pancreatic $\beta$-cells; HepG2, human hepatocyte carcinoma cell line; HCT-116, human colon carcinoma cell line; MCF-7, human breast cancer cell lines.

The most important obstacles in practical application of phytochemicals are difficulties in achieving their, previously established in the in vitro tests, active blood concentration. They undergo extensive biotransformation in the human body by enzymes of phase I and phase II of xenobiotics' metabolism. The metabolic pathway of $p$-methoxycinnamic acid was determined on a rabbit model, following both intravenous and oral administration. It was observed that $p$-MCA disappeared from the serum very rapidly when it was injected into the rabbit's blood. Maximum serum concentration $41 \mathrm{mg} / 100 \mathrm{~mL}$ was observed three minutes after injection of $100 \mathrm{mg} / \mathrm{kg}$ of $p$-MCA and its half-life was only $0.4 \mathrm{~h}$. The oral administration of the same dose resulted in very fast absorption from the digestive tract and slightly slower elimination from the serum. Peak concentration at the level of $7.38 \mathrm{mg} / 100 \mathrm{~mL}$ was obtained within 30-60 min after consumption but half-life was still lower than $1 \mathrm{~h}$ [16]. It was also reported that the main metabolite of $p$-methoxycinnamic acid identified in the serum is $p$-methoxybenzoic acid, which subsequently undergoes conjugation with glycine or glucuronic acid and in this form was excreted via urine [16]. In other studies, it has been reported that the radiolabeled [14C] 2-ethylhexyl-p-methoxycinnamate (EHMC) orally administered to rodents underwent rapid absorption and was excreted via urine after $72 \mathrm{~h}$ from consumption $(65-80 \%$ in rats and $63-72 \%$ in mice). In addition, it has been determined that EHMC is mainly distributed to adipose tissues, bladder, liver, kidney, and intestines [26].

In the recent years, several strategies for delivering and/or releasing therapeutic molecules have been proposed to improve their pharmacokinetic properties in the biological systems. In order to increase activity of ethyl $p$-methoxycinnamate (Ep-MCA) Kusumawati and Yusuf prepared its phospholipid complex [27]. Its oral administration to mice resulted in a two-fold increase in the analgesic activity of ester due to the fact that PC is highly absorbed from the digestive system and can circulate in the blood for a long time [28]. However, such complexes possess some limitations and are rather unstable. A better option is formation of more stable bioconjugates with direct covalent binding between biologically active molecule and lipid carrier. Clinical studies have proven that therapeutic molecules administrated in the form of lipid-drug conjugates (LDCs) are characterized by greater oral bioavailability and lower toxicity. Moreover, their release may be controlled in the body, and this form of application reduces their potential side effects [29]. Therefore, in recent years, several LDCs have been approved by Food and Drug Administratio (FDA) and European Medicines Agency, especially in the field of the treatment of diabetes, schizophrenia, and depression [30].

Lipases are enzymes whose biological function is to catalyze synthesis and hydrolysis of ester bonds in triacylglycerides [31]. However, due to their high specificity and selectivity they have found wide application in the biotechnology field [31]. They are often applied to the lipophilization process, even of non-natural for them, substrates such as sugars [32], amino acids [33], and phenolic 
compounds [34], carried out with different lipid carriers (fatty acids, fatty alcohols, acylglycerols, sterols, and phospholipids) delivering products with the desired physico-chemical properties, valuable for the pharmaceutical, food, and cosmetics industries. According to our best knowledge, little is known about enzymatic lyophilization of $p$-methoxycinnamic acid. Lee et al. synthesized octyl methoxycinnamate (OMC) by way of direct esterification reaction of $p$-MCA with 2-ethyl hexanol catalyzed by Novozym 435 at a temperature of $80^{\circ} \mathrm{C}$. The highest recorded level of conversion, $90 \%$, was obtained after $24 \mathrm{~h}$ of the reaction. The authors indicated in their report that high conversion of $p$-MCA was favored by the use of nonpolar organic solvents as the reaction medium. The OMC ester obtained as a product of this reaction is a compound that effectively absorbs UV-B rays; therefore, it has found wide application in the cosmetics industry as a non-allergenic sunscreen [35]. The process of its enzymatic synthesis was later studied also by Kumar and co-workers, who used the lipase form Rhizopus oryzae as the biocatalyst [36]. In their studies, a slightly higher conversion of $p$-MCA, on the level of $91.3 \%$, was observed in the reaction carried out in cyclo-octane at a temperature of $45{ }^{\circ} \mathrm{C}$. Octyl methoxycinnamate (OMC) was obtained in high yield, $88.6 \%$, after $96 \mathrm{~h}$ of reaction. Biological studies showed also that OMC exhibits better antioxidant activity than ascorbic acid and the free form of $p$-MCA as well as good antimicrobial activity against a series of pathogenic microorganisms. In 2006, Weber's research group presented the results of the enzymatic synthesis of long-chain alkyl $p$-methoxycinnamates, which are used in the food industry as lipophilic health-promoting additives. They performed the reaction of transesterification of methyl $p$-methoxycinnamate with oleyl alcohol (cis-9-octadecen-1-ol) at a temperature of $80^{\circ} \mathrm{C}$ for $72 \mathrm{~h}$ using three commercially available immobilized preparations of lipases (Novozym 435, Lipozyme RM IM, and Lipozyme TL IM). The highest degree of conversion of $p$-MCA (92\%) was obtained in the reaction catalyzed by lipase B from C. antarctica (Novozym 435). Lipase from R. miehei (Lipozyme RM IM) showed lower activity (60\% of conversion), while lipase from T. lanuginosus (Lipozyme TL IM) was basically unable to catalyze this reaction [37].

Enzymatic lyophilization of phenolic acids with fatty alcohols and triacylglycerols was extensively studied during the last two decades [38-40], whereas application of phospholipids for production of phenolipids is a new area of research [41,42]. There are only a few reports in the literature about modifications of phospholipids with phenolic acids and their $O$-methylated derivatives. In our previous research we reported chemical and enzymatic synthesis of phospholipid derivatives of selected O-methylated phenolic acids [43-47] and proved, in the in vitro tests, their higher anticancer [43] and antidiabetic [48] activity in comparison to the none-conjugated forms. Here, we focused on the development and optimization of the biotechnological process of production of bioconjugates of $p$-MCA with phosphatidylcholine with potential application as food additives and nutraceuticals. The use of lipases for this purpose can be beneficial, due to their broad substrate specificity and absence of any cofactor dependence. Furthermore, the currently available preparations of immobilized lipases at hydrophobic support allowed us to carry out biotechnological processes in the presence of an organic solvent and a high concentration of substrates with rewarding reaction efficiency and selectivity [49]. Hence, we performed lipase-catalyzed transesterification of egg-yolk phosphatidylcholine (PC) with $p$-methoxycinnamic acid ethyl ester (Ep-MCA) and evaluated such reaction parameters as biocatalyst, organic solvent, substrate molar ratio, enzyme loading, and reaction time. To minimize the costs of the process and at the same time more thoroughly analyze the relationships between variables, we applied Box-Behnken design (BBD), one of the most efficient statistical models of experiment.

\section{Results and Discussion}

\subsection{Screening of Lipase on the Interesterification Reaction}

We started our research from evaluation of four preparations containing different lipases (Lipozyme ${ }^{\circledR}$, Lipozyme TL IM, CALB, and Novozym 435) for their ability to catalyze the interesterification process between egg-yolk phosphatidylcholine and ethyl $p$-methoxycinnamate (Ep-MCA). Selection of lipases was made on the basis of the literature data indicating them as 
the most effective biocatalysts in the modifications of phenolic acids with acylglycerols [38,50,51] and phospholipids [32,41,45-47]. At the stage of lipases screening, reactions were incubated in the temperature of $50{ }^{\circ} \mathrm{C}$ in toluene using PC/E $p$-MCA molar ratio $1 / 10$ and $30 \%(w / w)$ of enzyme dosage. This combination of reaction parameters was taken as the starting point and was based on our previous experience and literature data. In several studies of lipase-catalyzed modification of phenolic acids, toluene was one of the most efficient reaction media [41,46]. An applied temperature of $50{ }^{\circ} \mathrm{C}$ was previously selected as the optimal during phospholipid modification with anisic acid [47], whereas the selected substrate molar ratio was the most efficient in the process of interesterification of PC with 3,4-dimethoxycinnamic acid ethyl ester [46]. The course of the reaction progress was monitored by evaluation of the degree of $p$-MCA incorporation into the phospholipid fraction phosphatidylcholine/lysophosphatidylcholine (PC/LPC) in selected time intervals (1, 2, 3, and 4 days) and the results are presented in Figure 1. For this purpose, samples of rection mixtures were collected, purified by the solid phase extraction (SPE) (Section 3.2), and then analyzed by gas chromatography (GC) (Section 3.5.2). Two from four evaluated biocatalysts, Lipozyme RM IM and Lipozyme TL IM, were not active under the proposed reaction conditions, while lipases CALB and Novozym 435 showed the ability to catalyze the process of incorporation of $p$-MCA into phospholipid fraction. In the reaction catalyzed by Novozym 435, the incorporation of $p$-MCA reached a maximum $19 \mathrm{~mol} \%$ within three days, whereas in CALB-catalyzed interesterification only $3 \mathrm{~mol} \%$ incorporation was observed. These results are the next ones, which confirm that among commercially available lipases preparations, Novozym 435 seems to be the most effective biocatalyst in the field of lipid modification with heterogeneous molecules. Based on this, we selected this enzyme for our further study.

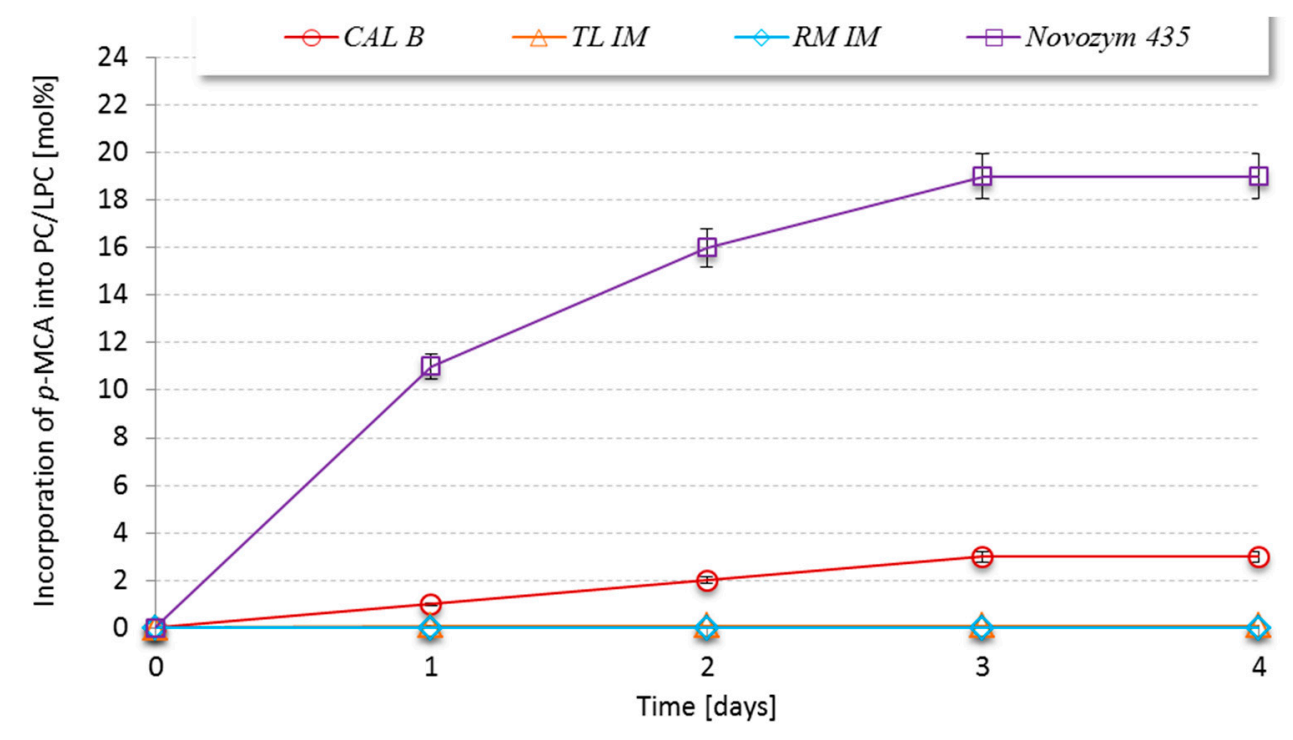

Figure 1. Time course of different lipase-catalyzed interesterification of PC with Ep-MCA. Reaction conditions: Toluene; PC/Ep-MCA, 1/10; lipase dosage $30 \%(w / w) ; 50{ }^{\circ} \mathrm{C}$.

\subsection{Effect of Reaction Medium on the Interesterification Reaction}

The presence of substrate-solvent interactions determines the availability of substrate to an enzyme. Therefore, the choice of solvent is very important for the productivity of the enzymatic reactions. During the selection of an appropriate reaction medium, four main factors should be taken under consideration: Solubilization of substrate, maintenance of enzyme activity and stability, the recovery of reactants, and the toxicity. The main problem during enzymatic lyophilization of phenolic acids is their poor solubility in hydrophobic solvents that are dedicated to lipase-catalyzed reactions. It is postulated that solvents with $\log P$ values $<2$ are not suitable for enzyme-catalyzed systems because they can distort the essential water from the lipases, thereby inactivating them. For instance, Patil et al. performed lipase-catalyzed modifications of phenolic acids with glycerol 
in polar solvents such as acetone, ethyl methyl ketone, acetonitrile, and 1,4-dioxane [52]. However, despite the increase in acid solubility in these reaction media, no increase in conversion was observed and use of a more hydrophobic medium was necessary to obtain a desirable product. The literature reports specify that the most proper solvents for lipase-catalyzed reactions are those with $\log P$ in the range of $2-4$. In our study, three hydrophobic solvents, like toluene $(\log P=2.5)$, hexane $(\log P=3.5)$, and heptane $(\log P=4)$, were screened to optimize the reaction of interesterification of PC with $p$-MCA. In addition, since previous studies revealed that binary solvent systems are highly efficient in the PC modification with phenolic molecules, mixture of toluene/chloroform in the volume ratio 9:1 $(\log P=2.5 / 2.01)$ was also tested $[41,47]$.

The second approach to increase solubility of substrates is to raise the reaction temperature. However, it has to be borne in mind that use of enzymes, even in immobilized form commonly considered as stable, in the presence of high temperature and at the same time with detergent-like molecules (fatty acids, phospholipids, etc.) can cause damage of the enzymes' carrier and lead to so-called enzyme "leakage". This phenomenon is consequently associated with partial loss of enzyme activity as well as loss of control over the course of the enzymatic process [53]. Thus, in our recently published studies, we used as an acyl donors' esters of phenolic acids $[45,46]$, which has a lower melting point and at the same time higher $\log P$ value when compare to corresponding acid, which makes them dissolve better in hydrophobic media under mild reaction temperature. Driven by these observations, also in this research in order to get well-dissolved substrate in selected hydrophobic media during the modified phospholipids' synthesis, we applied ethyl $p$-methoxycinnamate (Ep-MCA) (melting point: $49-50{ }^{\circ} \mathrm{C} ; \log P=3.07$ ) as an acyl donor.

From the results presented in Figure 2 it can be observed that reaction of interesterification of PC with E $p$-MCA proceeded in all selected solvents. However, the reaction environment had a significant impact on the degree of incorporation. For solvents with higher values of $\log P$, the level of incorporation was relatively low, only about 9 and $6 \mathrm{~mol} \%$ after three and four days of reaction for heptane and hexane, respectively. Toluene proved to be a better solvent for interesterification of PC with methoxylated derivative of cinnamic acid, giving $19 \mathrm{~mol} \%$ of incorporation after two days of reaction. The best results were obtained for reaction carried out in a binary solvent system. Using as a reaction medium a mixture of toluene with $1 / 10$ amount of chloroform, $29 \mathrm{~mol} \%$ of incorporation was achieved. These results are in accordance with a previously published paper, and a relatively high degree of incorporation was obtained in the toluene/chloroform $(9: 1(v / v)$ reaction mixture during interesterification of PC with ethyl ferulate [45] and acidolysis of PC with anisic acid [47]. Therefore, the mixture of toluene/chloroform 9:1 $(v / v)$ was selected as the medium for further evaluation of Novozym 435-catalyzed PC modifications.

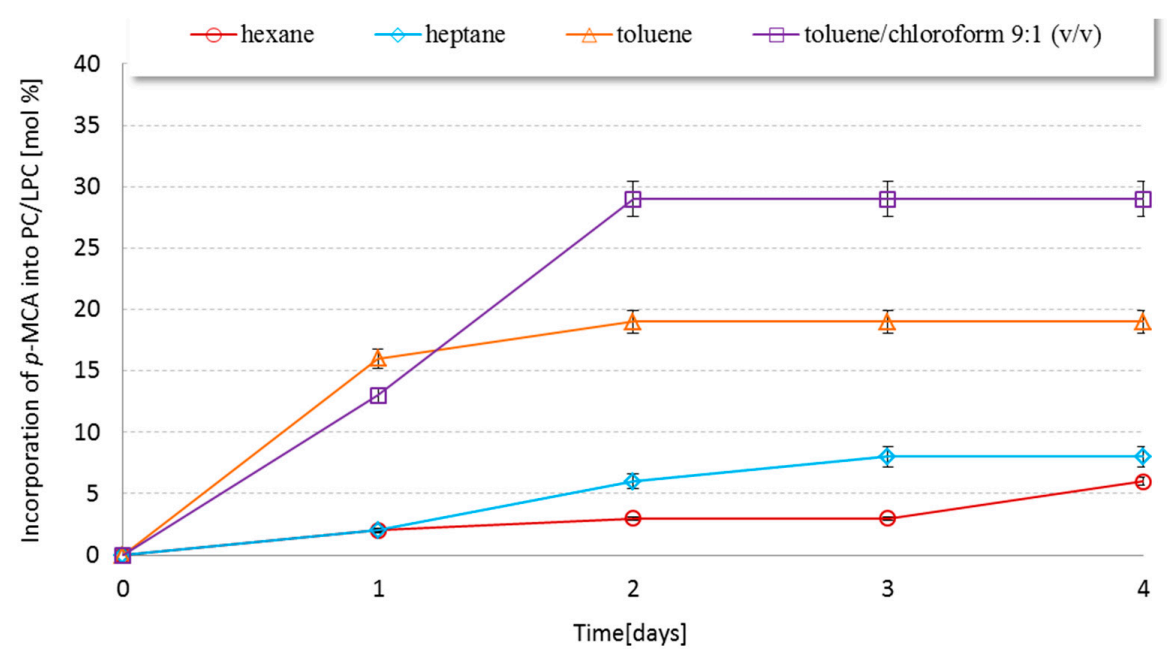

Figure 2. Effect of organic medium on the incorporation of $p$-MCA into phospholipids (PLs). Reaction conditions: PC/Ep-MCA, 1/10; Novozym $43530 \%(w / w) ; 50{ }^{\circ} \mathrm{C}$. 


\subsection{Development of Response Surface Methodology (RSM) Model}

The process of lipase-catalyzed interesterification of PC with $p$-MCA depends not only on the basal reaction parameters, such as biocatalyst and reaction medium, but its course varies during the time, depending also strongly on the reaction mixture composition and enzyme load. Due to that, in the next step of studies these reaction parameters, including PC/E $p$-MCA molar ratio, enzyme load, and reaction time (independent variables), on the degree of incorporation of $p$-MCA into the phospholipid fraction (dependent variable) were investigated using 3-level-3-factor Box-Behnken model with three central replicates. Values of independent variables and degrees of incorporation, determined experimentally as well as calculated using model equation (Section 3.3), are presented in the Table 2.

Table 2. Box-Behnken design matrix for three independent variables on incorporation of $p$-methoxycinnamic acid ( $p$-MCA) into phospholipid fraction (PC/LPC).

\begin{tabular}{|c|c|c|c|c|c|}
\hline Run & $\begin{array}{c}\text { Substrate } \\
\text { Molar Ratio } \\
\text { PC/E } p \text {-MCA }\end{array}$ & $\begin{array}{c}\text { Enzyme Load } \\
{[\%]}\end{array}$ & $\begin{array}{c}\text { Reaction Time } \\
\text { [days] }\end{array}$ & $\begin{array}{c}\text { Incorporation of } \\
p \text {-MCA into } \\
\text { PC/LPC [mol\%] a } \\
\text { (Experimental) }^{\text {a }}\end{array}$ & $\begin{array}{c}\text { Incorporation of } \\
p \text {-MCA to PC/LPC } \\
\text { [mol\%] (Predicted) }\end{array}$ \\
\hline 1 & 5 & 20 & 3 & $15 \pm 0.2$ & 16 \\
\hline 2 & 15 & 20 & 3 & $7 \pm 0.4$ & 6 \\
\hline 3 & 5 & 40 & 3 & $17 \pm 0.3$ & 18 \\
\hline 4 & 15 & 40 & 3 & $9 \pm 0.6$ & 7 \\
\hline 5 & 5 & 30 & 2 & $21 \pm 0.8$ & 20 \\
\hline 6 & 15 & 30 & 2 & $8 \pm 0.5$ & 9 \\
\hline 7 & 5 & 30 & 4 & $21 \pm 0.7$ & 20 \\
\hline 8 & 15 & 30 & 4 & $9 \pm 0.5$ & 10 \\
\hline 9 & 10 & 20 & 2 & $23 \pm 0.3$ & 23 \\
\hline 10 & 10 & 40 & 2 & $24 \pm 0.3$ & 24 \\
\hline 11 & 10 & 20 & 4 & $23 \pm 0.1$ & 23 \\
\hline 12 & 10 & 40 & 4 & $24 \pm 0.2$ & 24 \\
\hline 13 & 10 & 30 & 3 & $29 \pm 0.5$ & 29 \\
\hline 14 & 10 & 30 & 3 & $29 \pm 0.6$ & 29 \\
\hline 15 & 10 & 30 & 3 & $29 \pm 0.4$ & 29 \\
\hline
\end{tabular}

${ }^{\text {a }}$ Data are presented as mean \pm standard deviation (SD) of two independent analyses.

Using Design of Experiments (DOE) methods for process optimization, it is important to verify the quality and statistical significance of the empirical model before proceeding to the results' evaluation. Therefore, at the beginning, we interpreted the F-value of the model as appropriate based on the $p$-value, which was significantly less than 0.05 . Furthermore, a high value of coefficient of determination, $\mathrm{R}^{2}=0.98771$, implies an almost perfect relationship between the model and the data. In addition, comparison of predicted and actual degrees of incorporation of $p$-MCA depicted in the Figure $3 \mathrm{~A}$ reveals significant correspondence between them. All these observations can be concluded as a highly satisfactory fit of the empirical model, which can be used to predict response, depending on the value of the input factors.

The effect of three independent factors on the reaction course, as well as interaction between them, can be discussed from analysis of variance (ANOVA), shown in Table 3 and Pareto chart, depicted in Figure 3B. Based on these data, it can be determined that among all tested parameters, statistically important were substrate molar ratio in quadratic $(Q)$ and linear $(L)$ terms and enzyme loading $(Q)$ $(p<0.05)$. It can also be observed that none of tested variables underwent linear interactions $\left(\mathrm{X}_{1} \mathrm{~L}\right.$ by $X_{3} L, X_{1} L$ by $X_{2} L, X_{2} L$ by $X_{3} L$ ) and, therefore, did not affect the incorporation degree, according to their significantly higher-than- $0.5 p$-value. It is worth noting that the bars shown on the Pareto chart (Figure 3B) are mostly expressed by positive values, which means that as the parameter increased incorporation also increased. Only the substrate molar ratio (L) was characterized by a negative value, leading us to conclude that this parameter can exert a reverse effect on this process and, after exceeding 
a certain value, it may cause a decrease in the degree of incorporation. These findings are in agreement with our previous observations from phospholipid modification with phenylpropanoid molecules, which clearly indicate that the most crucial parameter in this process is the molar ratio of substrates followed by the enzyme dose and time of the reaction $[45,46]$. Furthermore, Zheng et al. also concluded that, during dual-responses, surface-optimized, lipase-catalyzed synthesis of ferulated diacylglycerols, among all tested variables, the most affecting one was substrate molar ratio [54].
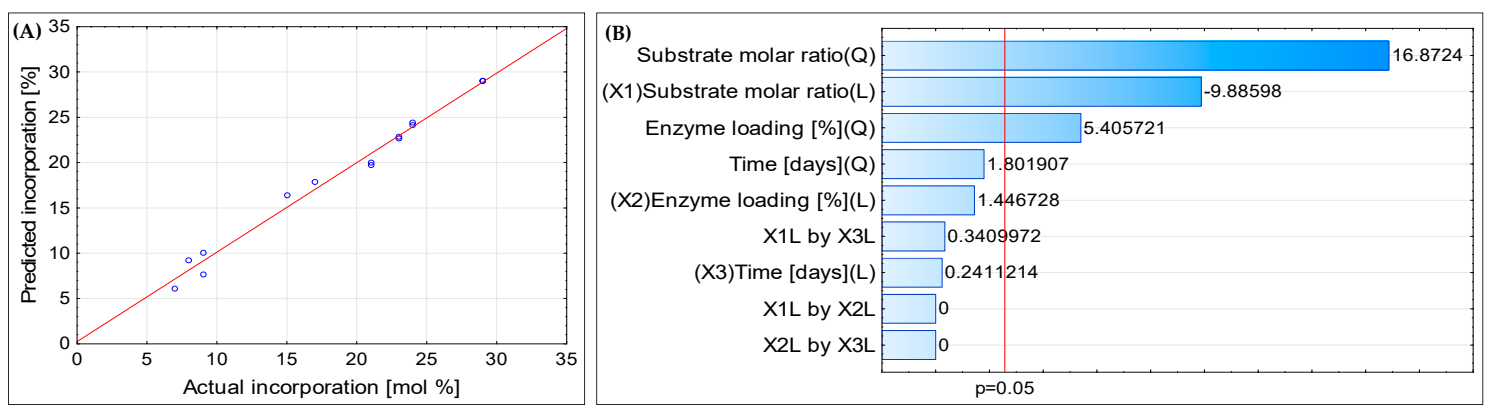

Figure 3. (A) Correlation of actual and predicted degrees of incorporation of $p$-MCA into phospholipids. (B) Pareto chart of the effect of the selected reaction parameters on the incorporation of $p$-MCA into phospholipids.

Table 3. Analysis of variance (ANOVA) for interesterification variables pertaining to the response of percent incorporation of $p$-MCA to PC/LPC.

\begin{tabular}{cccccc}
\hline Evaluated Factors & $\begin{array}{c}\text { Sum of } \\
\text { Squares }\end{array}$ & $\begin{array}{c}\text { Degrees of } \\
\text { Freedom }\end{array}$ & $\begin{array}{c}\text { Medium } \\
\text { Square }\end{array}$ & F-Value & $p$-Value \\
\hline$\left(\mathrm{X}_{1}\right)$ Substrate molar ratio $(\mathrm{L})$ & 210.1250 & 1 & 210.1250 & 97.7326 & 0.000181 \\
Substrate molar ratio (Q) & 612.0577 & 1 & 612.0577 & 284.6780 & 0.000013 \\
$\left(\mathrm{X}_{2}\right)$ Enzyme load (L) & 4.5000 & 1 & 4.5000 & 2.0930 & 0.207617 \\
Enzyme load (Q) & 62.8269 & 1 & 62.8269 & 29.2218 & 0.002929 \\
$\left(\mathrm{X}_{3}\right)$ Time of reaction (L) & 0.1250 & 1 & 0.1250 & 0.0581 & 0.819037 \\
Time of reaction (Q) & 6.9808 & 1 & 6.9808 & 3.2469 & 0.131434 \\
$\mathrm{X}_{1}$ by $\mathrm{X}_{2}$ & 0.0000 & 1 & 0.0000 & 0.00000 & 1.000000 \\
$\mathrm{X}_{1}$ by $\mathrm{X}_{3}$ & 0.2500 & 1 & 0.2500 & 0.1163 & 0.746968 \\
$\mathrm{X}_{2}$ by $\mathrm{X}_{3}$ & 0.0000 & 1 & 0.0000 & 0.0000 & 1.000000 \\
Error & 10.7500 & 5 & 2.1500 & & \\
Total error & 874.4000 & 14 & & & \\
$\mathrm{R}^{2}=0.98771$ & & & & & \\
\hline
\end{tabular}

In accordance with the Box-Behnken model, it is also possible to generate three-dimensional response surface plots, which allow for a pragmatic, and at the same time, comprehensible analysis of the relationship between input parameters (substrate molar ratio, enzyme loading, and reaction time) and the obtained response (degree of incorporation). In general, there are four types of three-dimensional plots for RSM analysis: Type I to Type IV [55]. Type I, also called "dome shaped", is one of the most characteristic for the lipases-catalyzed process [55]. In typical dome-shaped charts, there is a slight increase (almost linear) in one axis and a critical point in the other axis, after exceeding which no further increase of the dependent variable is observed. Figure 4 illustrates surface plots for effect of the two various reaction variables: (A) Reaction time and enzyme loading, (B) substrate molar and enzyme loading, and $(\mathrm{C})$ reaction time and substrate molar ratio on the incorporation of $p$-MCA into phospholipids, while the third independent is fixed at the central value. Based on Figure 4B,C, it can be observed that an increase in the ratio of PC/E $p$-MCA results in an increase in the degree of incorporation but only until a critical concentration of substrate ratio is reached. It suggests that up to molar ratio 1/10 of PC/E $p$-MCA the interesterification reaction is favored, but further increase in the concentration of the acyl donor no longer contributes to an increase of incorporation degree. It is 
possible that, beyond this value, competing lipid substrates (especially released free fatty acids) bind to the enzyme and limit acyl-enzyme complex formation, thus reducing the efficiency of the desirable interesterification reaction. This phenomenon was also observed in our earlier investigations with lipase-catalyzed modifications of phosphatidylcholine $[45,46,48,56]$. In addition, on Figure $4 A, C$ it is also visible that in the studied range there is no significant relationship between the reaction time and the degree of incorporation, and this factor is of little importance. Maximum incorporation $(29 \mathrm{~mol} \%)$ was achieved on the second day of the trial and remained stable until the fourth day. Subsequently, depicted on Figure 4, correlation between the incorporation and the content of the enzyme and the reaction time (Figure $4 \mathrm{~A}$ ) or ratio of the substance (Figure $4 \mathrm{C}$ ) indicates that increases of the enzyme dose in the range of 20 to $30 \%$ increases the incorporation and then, after exceeding this value, slightly decreases. It can be explained that, when a certain value of biocatalyst was reached $(30 \% w / w)$, a further increase in its dose does not cause improvements of the reaction productivity.
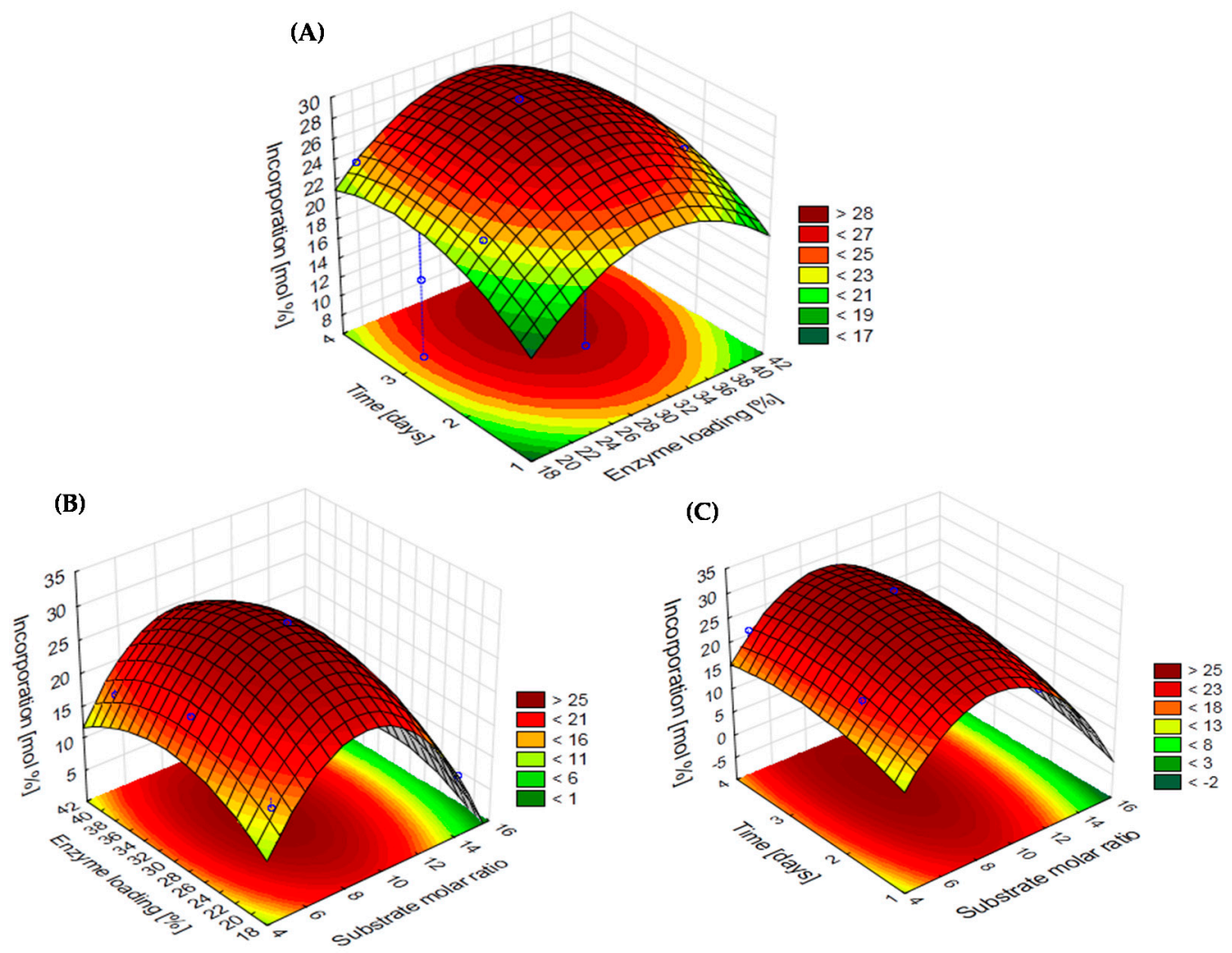

Figure 4. Response surface plots presenting effect of (A) time of reaction and enzyme loading, (B) enzyme loading and substrate molar ratio, (C) time of reaction and substrate molar ratio on the incorporation of $p$-MCA into phospholipids.

Summarizing, based on RSM analysis, the highest degree (29 mol\%) of incorporation of $p$-MCA into PC/LPC fraction was achieved when all evaluated independent variables were as follows: Substrate molar ratio PC/Ep-MCA 1/10, enzyme dosage 30\% w/w, and two days of the reaction time. Furthermore, changes in reaction time and enzyme content did not significantly affect the process, while the reduction of substrate molar ratio $(1 / 5)$ or its increase $(1 / 15)$ resulted in a high reduction of degree of incorporation.

\subsection{Identification of the Reaction Products}

Qualitative analysis of products of the reaction mixture was made using thin-layer chromatography (TLC) (Section 3.5.1) and high-performance liquid chromatography (HPLC). Products of reaction mixtures and standards (PC-egg yolk, LPC-egg yolk, Ep-MCA) were spotted on TLC plate and their $R_{\mathrm{f}}$ values were compared. As a result, we identified two new spots with $R_{\mathrm{f}}$ values of 0.03 and 0.35 
different than $\mathrm{R}_{\mathrm{f}}$ values of standards (PC-egg (0.45), LPC-egg (0.1), and Ep-MCA (0.69)). Their higher polarity being different than PC and LPC of egg yolk suggested that these were new products of the enzymatic modification. This hypothesis was further confirmed by HPLC and NMR analysis.

Degree of incorporation of $p$-MCA into phospholipid fraction (PC/LPC) was analyzed by gas chromatography (GC) (Section 3.5.2). Fatty acid composition of native PC and $p$-MCA-enriched phospholipid fraction are presented below in Table 4. Comparing acids' composition of native phosphatidylcholine and modified phospholipid fraction (PC/LPC), it is visible that egg-yolk PC contains much more saturated fatty acids, such as palmitic (16:0) and oleic (18:0) acid, than their structured fraction. It can be explained by the fact that these acids usually are distributed in the $s n-1$ position of egg-yolk PC and that during Novozym 435-catalyzed interesterification they undergo replacement by the $p$-methoxycinnamonyl acyl residue.

Table 4. Fatty acid composition (\% according to GC) of native egg-yolk PC and phospholipid fraction obtained in the interesterification reaction of PC with Ep-MCA.

\begin{tabular}{ccc}
\hline Fatty and 4MCA Acids & Native PC & Modified Phospholipid Fraction PC/LPC \\
\hline C16:0 (PA) & $34 \pm 0.2$ & $8 \pm 0.6$ \\
C16:1 (OPA) & $1 \pm 0.7$ & $1 \pm 0.1$ \\
C18:0 (SA) & $15 \pm 0.9$ & $8 \pm 0.9$ \\
C18:1 (OA) & $26 \pm 0.7$ & $23 \pm 0.3$ \\
C18:2 (LA) & $20 \pm 0.3$ & $22 \pm 0.7$ \\
C20:4 (AA) & $4 \pm 0.2$ & $9 \pm 0.4$ \\
$p$-MCA & - & $29 \pm 0.4$ \\
\hline
\end{tabular}

Modified phospholipid fraction was next analyzed by normal-phase, high-performance liquid chromatography (HPLC) equipped with a UV/CAD detector (at $300 \mathrm{~nm}$ ) according to the procedure described in Section 3.5.3. As can be seen from Figure 5, retention time of both new products' modified PC and modified LP were as follow: $\mathrm{R}_{\mathrm{f}}=11.067$ and $\mathrm{R}_{\mathrm{f}}=15.320$, respectively, for $p$-MCA-PC and $p$-MCA-LPC.

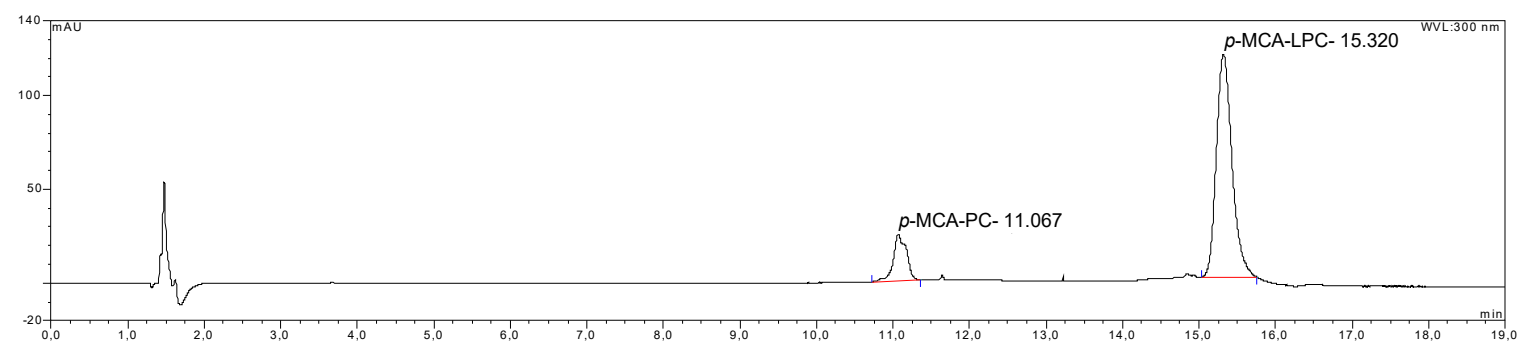

Figure 5. Chromatogram of fraction of modified phosphatidylcholine obtained by HPLC analysis with UV/CAD detector.

Based on the optimized parameters (reaction medium toluene/chloroform 9:1 v/v, enzyme dosage $30 \% w / w$ of Novozym $435,1 / 10$ substrate molar ratio PC/E $p$-MCA, reaction time of two days, and reaction temperature $50^{\circ} \mathrm{C}$ ), the interesterification reaction of natural phosphatidylcholine with E $p$-MCA was next performed on a larger scale. Phospholipids were extracted from the reaction mixtures and purified by column chromatography (Section 3.4). The major product, $p$-methoxycinnamoylated lysophosphatidylcholine ( $p$-MCA-LPC), was obtained in (high) 32\% of isolated yield. The second identified product isolated in trace amount, only in 3\% isolated yield, was $p$-methoxycinnamoylated phosphatidylcholine ( $p$-MCA-PC). The chemical structure of $p$-MCA-LPC was fully characterized by NMR $\left({ }^{1} \mathrm{H},{ }^{13} \mathrm{C},{ }^{31} \mathrm{P}\right)$ spectral data (Section 3.5.4). On the ${ }^{1} \mathrm{H}$ NMR spectrum protons from p-methoxycinnamic acid, including signals from aromatic ring $(6.70-7.48 \mathrm{ppm})$, olefinic protons (6.14 ppm and $7.47 \mathrm{ppm}$ ) and protons of methoxy group (3.63 ppm) were identified. Also, protons 
from phospholipid backbone (-N $\left(\mathrm{CH}_{3}\right)_{3}$ (3.06 ppm), $\mathrm{CH}_{2}-\beta$ (3.54 ppm), $\mathrm{CH}_{2}-3^{\prime}$ (3.70-3.78 ppm), $\mathrm{H}-2^{\prime}$ (3.81 ppm), $-\mathrm{OH}(3.88 \mathrm{ppm}), \mathrm{CH}_{2}-1^{\prime}$, and $\mathrm{CH}_{2}-\alpha(4.00-4.08 \mathrm{ppm}$ ), were clearly detected (Supplementary Materials).

Scheme of the Novozym 435-catalyzed synthesis of $p$-methoxycinnamoylated phospholipids in the reaction of interesterification between the egg-yolk PC and Ep-MCA is proposed below (Figure 6). The process begins by being catalyzed by Novozyme 435 hydrolysis of native PC and formation of 2-acyl-LPC-egg yolk. In the next step, free hydroxyl group, in the sn-1 position of formed lysophospholipid, is esterified with an $p$-methoxycinnamic acid ethyl ester, giving the first product of the reaction, 1-(4-methoxy) cinnamoyl-2-acyl-sn-glycero-3-phosphocholine ( $p$-MCA-PC). A probable reason for such a low efficiency in the $p$-MCA-PC synthesis is that 2-acyl-LPC is subjected to 1-acyl-LPC as a result of fatty acid migration from $s n-2$ to $s n-1$ position, leading to glycerophosphocholine (GPC), which is an intermediate product next transformed into the main product of the enzymatic interesterification $p$-MCA-LPC. This pathway, based mostly on the formation of GPC as the intermediate product, confirmed its presence in the reaction mixtures identified during TLC and HPLC analyses. Obtained results are in accordance with previously published data about the synthesis of phenophospholipids [45-47].

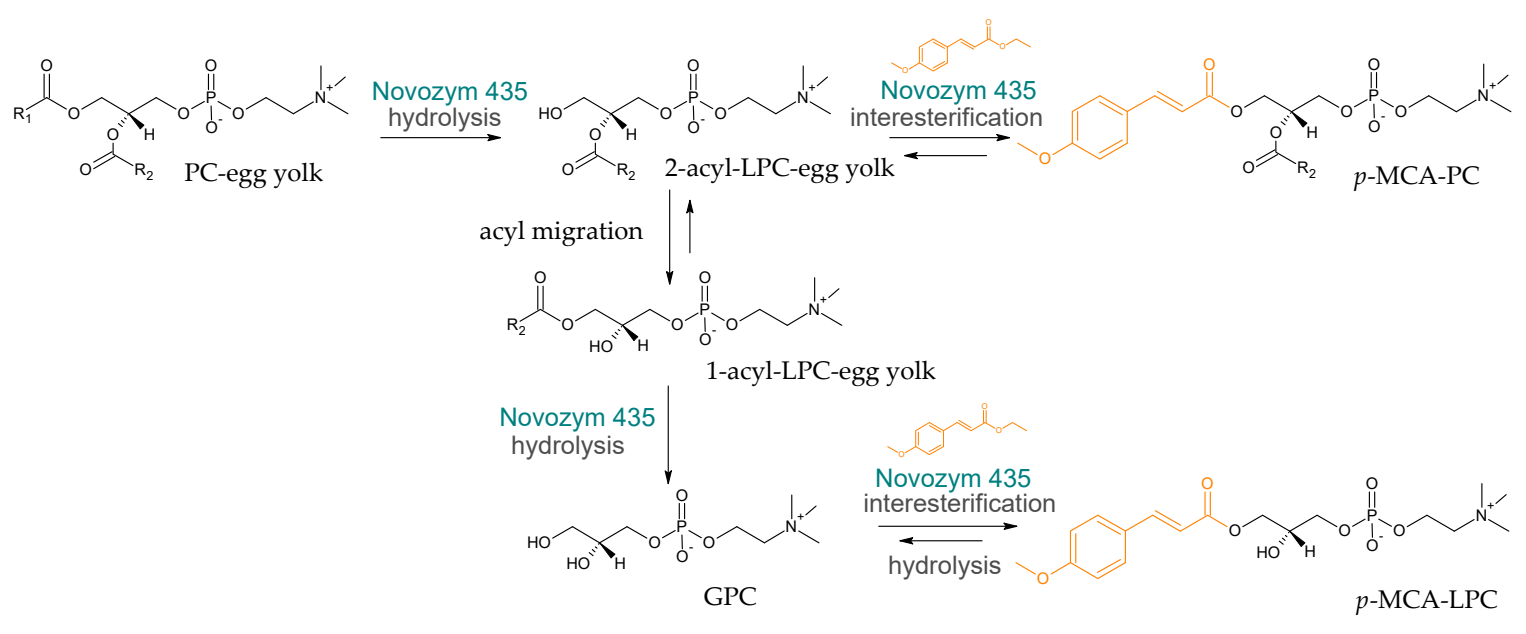

Figure 6. Possible changes occurring during the enzymatic interesterification of egg-yolk (PC) phosphatidylcholine with ethyl $p$-methoxycinnamate (Ep-MCA).

\section{Materials and Methods}

\subsection{Substrates, Chemicals, and Enzymes}

Ethyl $p$-methoxycinnamate (Ep-MCA) was synthesized (82\% yield) according to the procedure described before [57] and its spectroscopic data were confirmed with the literature [58]. High, 98\%, purity of E $p$-MCA was verified by GC. Native egg-yolk phosphatidylcholine (PC), used as a substrate for interesterification reaction, was obtained and purified according to the previously presented protocol [56].

Immobilized lipases used in the research were purchased from Sigma-Aldrich from St. Louis, MO, USA (Candida antarctica: Novozym ${ }^{\circledR} 435(>5000 \mathrm{U} / \mathrm{g}$ ) and CALB (>1800 U/g)), Fluka from Buchs, Switzerland (Rhizomucor miehei Lipozyme ${ }^{\circledR}$ RM IM (>30 U/g)), and Novozymes A/S from Bagsvaerd, Denmark (Thermomyces lanuginosus Lipozyme ${ }^{\circledR}$ TL IM $250 \mathrm{U} / \mathrm{g}$ ). The trans p-methoxycinnamic acid (4MCA), sodium methylate, and boron trifluoride methanol complex solution $\left(13-15 \% \mathrm{BF}_{3} \times \mathrm{MeOH}\right)$ were purchased from Sigma-Aldrich (St. Louis, MO, USA). All organic solvents used in the enzymatic reactions and chromatography, silica gel-coated aluminum plates (Kieselgel 6-F254, $0.2 \mathrm{~mm}$ ), and the silica gel (Kieselgel 60, 230-400 mesh) used in the column chromatography were purchased from Merck (Darmstadt, Germany). 


\subsection{Enzymatic Interesterification of $P C$ with $E p-M C A$}

At the beginning of the experiments, four lipases (Novozym 435, CALB, Lipozyme RM IM, and Lipozyme TL IM) were tested for interesterification reaction of egg-yolk phosphatidylcholine (PC) with ethyl $p$-methoxycinnamate (Ep-MCA). For this purpose, $20 \mathrm{mg}$ of PC $(0.026 \mathrm{mmol})$ were mixed on the magnetic stirrer (300 rpm) with Ep-MCA at 1/10 molar ratio in $2 \mathrm{~mL}$ of toluene and $\mathrm{N}_{2}$ atmosphere. When the substrate solution reached reaction temperature of $50{ }^{\circ} \mathrm{C}, 30 \%$ of appropriate immobilized lipase (calculated by total weight of substrates) was added. In another set of experiments, the type of organic solvent (heptane, hexane, toluene, and toluene:chloroform 9:1 (v/v) were also studied using Novozym 435 as a biocatalyst. All experiments were carried out in triplicate.

Interesterification reactions were stopped at the selected time intervals (1, 2, 3, and 4 days), by enzyme filtration on G4 Shott funnel with Celite layer. Then, phospholipids were separated from residue-unreacted ester and released fatty acids using silica gel columns (Discovery ${ }^{\circledR}$ DSC-Si SPE, 52654-U $500 \mathrm{mg}$ ) and SPE methodology [56]. Purified and concentrated phospholipid fractions were first qualitatively analyzed by thin-layer chromatography (TLC) (Section 3.5.1) and then their acid profile was quantitatively analyzed by gas chromatography (GC) procedure (Section 3.5.2).

\subsection{Design of Experiment}

In order to optimize reaction parameters, such as molar ratio of substrate, enzyme loading, and reaction time, 3-factor, 3-level Box-Behnken design was employed, which required 15 runs of experiments (Table 1). The independent variables in the selected Design of Experiment (DOE) of egg-yolk phosphatidylcholine interesterification with E $p$-MCA were substrate molar ratio of PC/E $p$-MCA (1/5, 1/10, 1/15), enzyme loading $(20,30,40 \%)$, and reaction time $(2,3,4$ days), while the only dependent variable was incorporation [mol \%] based on GC analysis. We used STATISTICA 13.3 (StatSoft, Inc.) software to generate the polynomial equation of the model (Equation (1)):

$$
Y_{i}=\beta_{0}+\beta_{1} X_{1}+\beta_{2} X_{2}+\beta_{3} X_{3}+\beta_{12} X_{1} X_{2}+\beta_{13} X_{1} X_{3}+\beta_{23} X_{2} X_{3}+\beta_{11} X_{1}^{2}+\beta_{33} X_{3}^{2}
$$

where $Y_{i}$ is predicted response, $\beta_{0}$ is model constant, $X_{1}-X_{3}$ are independent variables, and $\beta_{1}-\beta_{33}$ are regression coefficients. All experiments were carried out in two independent analyses and the averages of incorporation were taken as response.

\subsection{Large-Scale Interesterification of PC with Ep-MCA Catalyzed by Novozym 435}

Interesterification of PC with ethyl $p$-methoxycinnamate was next successfully performed in the large scale. In this case, egg-yolk phosphatidylcholine $(200 \mathrm{mg}, 0.26 \mathrm{mmol})$ and Ep-MCA (at molar ratio PC/E4MCA, 1/10) were mixed in $20 \mathrm{~mL}$ of the solvent mixture of toluene/chloroform 9:1 $(\mathrm{v} / \mathrm{v})$ on a magnetic stirrer (300 rpm). Three-day reaction was carried out in $\mathrm{N}_{2}$ atmosphere, at $50{ }^{\circ} \mathrm{C}$, in a presence of $30 \%$ of Novozym 435 . After this time, reaction mixture was filtered on G4 Shott funnel with Celite, and solvent was evaporated in vacuo. Reaction products were purified next by column chromatography, according to the procedure described before [45]. Purified products' fractions (PC-egg, LPC-egg, modified phosphatidylcholine ( $p$-MCA-PC), and modified lysophosphatidylcholine ( $p$-MCA-LPC)) were analyzed by TLC plates (Section 3.5.1), GC, and HPLC. The structure of major product, $p$-MCA-LPC, was confirmed NMR spectroscopy $\left({ }^{1} \mathrm{H},{ }^{13} \mathrm{C},{ }^{31} \mathrm{P}\right)$.

\subsection{Analytical Methods}

\subsubsection{Thin-Layer Chromatography (TLC)}

Thin-layer chromatography (TLC) was employed to control interesterification reactions' progress and for qualitative analysis of the reaction products. Samples were dissolved in chloroform, spotted on TLC plates, eluted with the mixture of chloroform/methanol/water (65:25:4, v/v/v), and next identified 
by spraying the TLC plates with the $0.05 \%$ primuline solution (acetone:water, $8: 2, v / v$ ) and then exposing them to UV light $(\lambda=365 \mathrm{~nm})$.

\subsubsection{Gas Chromatography (GC)}

Analysis of acid profile of interesterification products (PC-egg, LPC-egg, $p$-MCA-PC, $p$-MCA-LPC) and standards (PC-egg, $p$-MCA) was performed by gas chromatography (GC). All purified samples by SPE or column chromatography methods were derivatized into corresponding methyl esters, according to the procedure described before [45]. Then methyl esters were analyzed on an Agilent $6890 \mathrm{~N}$ instrument equipped with HP-88 column $(100 \mathrm{~m} \times 0.25 \mathrm{~mm} \times 0.2 \mu \mathrm{m})$, manufactured by Agilent (Santa Clara, CA, USA). Initial oven temperature was set at $110{ }^{\circ} \mathrm{C}$, then raised to $200{ }^{\circ} \mathrm{C}$ (rate of $5{ }^{\circ} \mathrm{C} / \mathrm{min}$ ), and next to $250{ }^{\circ} \mathrm{C}$ at $2{ }^{\circ} \mathrm{C} / \mathrm{min}$, and held there for $5 \mathrm{~min}$. The total analysis time was $48 \mathrm{~min}$. The injector temperature and the flame ionization detector temperatures were set at $250^{\circ} \mathrm{C}$. Retention times of the fatty acid methyl esters (FAME) were compared with retention time of a standard FAME mixture (Supelco 37 FAME Mix) obtained from Sigma Aldrich. GC Chemstation Version A.10.02 was used for the quantitative analysis of $p$-methoxycinnamic acid incorporation into phospholipid fraction, calculated as $\mathrm{mol} \%$ based on the peak areas.

\subsubsection{High-Performance Liquid Chromatography (HPLC)}

Phospholipid fraction, obtained from the optimized interesterification reaction performed in the larger scale, was analyzed by HPLC. To determine PC-egg, LPC-egg, $p$-MCA-PC, and $p$-MCA-LPC in the purified product mixture, DIONEX UltiMate 3000 chromatograph from Thermo Fisher Scientific (Olten, Switzerland) equipped with UV/CAD detector (at $300 \mathrm{~nm}$ ) and BetaSil DIOL column (Thermo Scientific, $150 \times 4.6 \mathrm{~mm}, 5 \mu \mathrm{m}$ ) were used. In this analysis, the injection volume was $15 \mu \mathrm{L}$, whereas autosampler and column temperature were 20 and $30{ }^{\circ} \mathrm{C}$, respectively. The elution was set at constant flow $(1.5 \mathrm{~mL} / \mathrm{min})$ and performed in a gradient: solvent A $(1 \% \mathrm{HCOOH}, 0.1 \%$ triethylamine (TEA) in water), solvent $B$ (hexane), and solvent $C$ (2-propanol). The elution program was as follows: $3 / 40 / 57$ $(\% \mathrm{~A} / \% \mathrm{~B} / \% \mathrm{C}(v / v / v))$, at $5 \mathrm{~min}=10 / 40 / 50$, at $9 \mathrm{~min}=10 / 40 / 50$, at $9.1 \mathrm{~min}=3 / 40 / 57$, and at $19 \mathrm{~min}=43 / 40 / 57$. Total analysis time was $19 \mathrm{~min}$.

\subsubsection{Spectroscopic Spectra (NMR)}

In order to confirm the structure of obtained products, NMR analysis was conducted. However, due to the trace amount of the obtained modified PC ( $p$-MCA-PC), NMR experiments were performed only for modified LPC ( $p$-MCA-LPC). A sample of purified $p$-MCA-LPC was dissolved in $0.6 \mathrm{~mL}$ of $\mathrm{CDCl}_{3} / \mathrm{MeOH}(2: 1, v / v)$ in NMR tube and then analyzed on a Bruker Advance II $600 \mathrm{MHz}$ spectrometer (Bruker, Billerica, MA, USA).

1-(4-methoxy) cinnamoyl-2-hydroxy-sn-glycero-3-phosphocholine (p-MCA-LPC)

Colorless, greasy solid (32\% yield, $\left.\mathrm{R}_{\mathrm{f}} 0.03\right) ;{ }^{1} \mathrm{H}$ NMR (600 MHz, $\left.\mathrm{CDCl}_{3} / \mathrm{CD}_{3} \mathrm{OD} 2: 1(v / v)\right), \delta: 3.06$ $\left(\mathrm{s}, 9 \mathrm{H},-\mathrm{N}\left(\mathrm{CH}_{3}\right)_{3}\right), 3.54\left(\mathrm{~s}, 2 \mathrm{H}, \mathrm{CH}_{2}-\beta\right), 3.63\left(\mathrm{~s}, 3 \mathrm{H},-\mathrm{OCH}_{3}\right), 3.70-3.78\left(\mathrm{~m}, 2 \mathrm{H}, \mathrm{CH}_{2}-3^{\prime}\right), 3.81\left(\mathrm{~s}, 1 \mathrm{H}, \mathrm{H}-2^{\prime}\right)$, $3.88(\mathrm{~s}, 1 \mathrm{H},-\mathrm{OH}), 4.00-4.08\left(2 \mathrm{~m}, 4 \mathrm{H}, \mathrm{CH}_{2}-1^{\prime}, \mathrm{CH}_{2}-\alpha\right), 6.14(\mathrm{~d}, 1 \mathrm{H}, J=15.9 \mathrm{~Hz}, \mathrm{H}-2), 6.71\left(\mathrm{~m}, 2 \mathrm{H}, \mathrm{H}-3^{\prime \prime}\right.$, H-5"), 7.30 (m, 2H, H-2" , H-6"), 7.48 (d, $1 \mathrm{H}, J=15.9 \mathrm{~Hz}, \mathrm{H}-3) ;{ }^{13} \mathrm{C} \mathrm{NMR}\left(150 \mathrm{MHz}, \mathrm{CDCl}_{3} / \mathrm{CD}_{3} \mathrm{OD} 2: 1\right.$ $(v / v))$ 8: $54.11\left(\left(-\mathrm{N}\left(\mathrm{CH}_{3}\right)_{3}\right), 55.22\left(-\mathrm{OCH}_{3}\right), 59.64(\mathrm{C}-\alpha), 63.75\left(\mathrm{C}-1^{\prime}\right), 64.95(\mathrm{C}-\beta), 66.24\left(\mathrm{C}-3^{\prime}\right), 68.57\left(\mathrm{C}-2^{\prime}\right)\right.$, 113.38 (C-2), 114.36 (Ar), 126.76 (Ar), 129.87 (Ar), 145.61 (C-3), 161.73.21 (Ar), 167.80 (C-1); ${ }^{31} \mathrm{P}$ NMR $\left(243 \mathrm{MHz}, \mathrm{CDCl}_{3} / \mathrm{CD}_{3} \mathrm{OD} 2: 1(v / v)\right) \delta:-5.08$.

\section{Conclusions}

In the present paper, we developed a novel biotechnological method for the synthesis of phospholipids structured with $p$-methoxycinnamic acid. During the studies, we proved that Novozym 435 is a lipase preparation that was the most effective among the tested biocatalysts and can be 
successfully applied for the process of lyophilization of $p$-methoxycinnamic acid. In addition, we clearly demonstrated that course of incorporation of $p$-MCA into phospholipids varied during the time and strongly depended on the reaction mixture composition and enzyme load. In order to optimize crucial parameters, we conducted experiments according to Box-Behnken model and, based on these, we were able to observe that the most important factor was molar ratio of substrates. HPLC and NMR analyses confirmed that the products of modification were $p$-MCA-LPC, which was formed in $32 \%$ isolated yield and $p$-MCA-PC, which was isolated only in a trace amount (yield $=3 \%$ ). Both of these products have not yet been described in the literature and are promising in the context of production of new nutraceuticals based on the natural products.

Supplementary Materials: The following are available online at http://www.mdpi.com/2073-4344/10/10/1181/s1, Figure S1: ${ }^{1} \mathrm{H}$ NMR spectrum of $p$-MCA-LPC, Figure S2: ${ }^{13} \mathrm{C}$ NMR spectrum of $p$-MCA-LPC, Figure S3: ${ }^{31} \mathrm{P}$ NMR spectrum of $p$-MCA-LPC, Figure S4: GC chromatogram of PC-egg (standard), Figure S5: GC chromatogram of p-MCA (standard), Figure S6: GC chromatogram of PLs

Author Contributions: Conceptualization, A.G.; methodology, M.R. and A.G.; validation, A.G.; investigation, M.R.; writing—original draft preparation, M.R. and A.G.; writing-review and editing, M.R. and A.G.; visualization, M.R. and A.G.; supervision, A.G. All authors have read and agreed to the published version of the manuscript.

Funding: Article Processing Charge (APC) was financed under the Leading Research Groups' support project from the subsidy increased for the period 2020-2025 in the amount of $2 \%$ of the subsidy referred to Art. 387 (3) of the Law of 20 July 2018 on Higher Education and Science, obtained in 2019.

Conflicts of Interest: The authors declare no conflict of interest.

\section{References}

1. Fernandez-Martinez, E.; Bobadilla, R.; Morales-Rios, M.; Muriel, P.; Perez-Alvarez, V. Trans-3-Phenyl-2-Propenoic Acid (Cinnamic Acid) Derivatives: Structure-Activity Relationship as Hepatoprotective Agents. Med. Chem. 2007, 3, 475-479. [CrossRef] [PubMed]

2. Adisakwattana, S.; Sookkongwaree, K.; Roengsumran, S.; Petsom, A.; Ngamrojnavanich, N.; Chavasiri, W.; Deesamer, S.; Yibchok-anun, S. Structure-activity relationships of trans-cinnamic acid derivatives on $\alpha$-glucosidase inhibition. Bioorg. Med. Chem. Lett. 2004, 14, 2893-2896. [CrossRef] [PubMed]

3. Adisakwattana, S.; Roengsamran, S.; Hsu, W.H.; Yibchok-Anun, S. Mechanisms of antihyperglycemic effect of p-methoxycinnamic acid in normal and streptozotocin-induced diabetic rats. Life Sci. 2005, 78, 406-412. [CrossRef] [PubMed]

4. Yibchok-Anun, S.; Adisakwattana, S.; Moonsan, P.; Hsu, W.H. Insulin-secretagogue activity of p-methoxycinnamic acid in rats, perfused rat pancreas and pancreatic $\beta$-cell line. Basic Clin. Pharmacol. Toxicol. 2008, 102, 476-482. [CrossRef]

5. Adisakwattana, S.; Moonsan, P.; Yibchok-Anun, S. Insulin-releasing properties of a series of cinnamic acid derivatives in vitro and in vivo. J. Agric. Food Chem. 2008, 56, 7838-7844. [CrossRef]

6. Kim, S.R.; Kim, Y.C. Neuroprotective phenylpropanoid esters of rhamnose isolated from roots of Scrophularia buergeriana. Phytochemistry 2000, 54, 503-509. [CrossRef]

7. Kim, S.R.; Sung, S.H.; Jang, Y.P.; Markelonis, G.J.; Oh, T.H.; Kim, Y.C. E-p-Methoxycinnamic acid protects cultured neuronal cells against neurotoxicity induced by glutamate. Br. J. Pharmacol. 2002, 135, 1281-1291. [CrossRef]

8. Kim, S.R.; Kang, S.Y.; Lee, K.Y.; Kim, S.H.; Markelonis, G.J;; Oh, T.H.; Kim, Y.C. Anti-amnestic activity of E-p-methoxycinnamic acid from Scrophularia buergeriana. Cogn. Brain Res. 2003, 17, 454-461. [CrossRef]

9. Gunasekaran, S.; Venkatachalam, K.; Namasivayam, N. Anti-inflammatory and anticancer effects of p-methoxycinnamic acid, an active phenylpropanoid, against 1,2-dimethylhydrazine-induced rat colon carcinogenesis. Mol. Cell. Biochem. 2019, 451, 117-129. [CrossRef]

10. Andrade, P.B.; Leitão, R.; Seabra, R.M.; Oliveira, M.B.; Ferreira, M.A. 3,4-Dimethoxycinnamic acid levels as a tool for differentiation of Coffea canephora var. robusta and Coffea arabica. Food Chem. 1998, 61, 511-514. [CrossRef]

11. Sobolev, V.S.; Horn, B.W.; Potter, T.L.; Deyrup, S.T.; Gloer, J.B. Production of stilbenoids and phenolic acids by the peanut plant at early stages of growth. J. Agric. Food Chem. 2006, 54, 3505-3511. [CrossRef] 
12. Duarte-Almeida, J.M.; Negri, G.; Salatino, A.; de Carvalho, J.E.; Lajolo, F.M. Antiproliferative and antioxidant activities of a tricin acylated glycoside from sugarcane (Saccharum officinarum) juice. Phytochemistry 2007, 68, 1165-1171. [CrossRef]

13. Hudson, E.A.; Dinh, P.A.; Kokubun, T.; Simmonds, M.S.J.; Gescher, A.; Laboratory, J. Characterization of Potentially Chemopreventive Phenols in Extracts of Brown Rice That Inhibit the Growth of Human Breast and Colon Cancer Cells. Cancer Epidemiol. Biomark. Prev. 2000, 9, 1163-1170.

14. Sivagami, G.; Karthikkumar, V.; Balasubramanian, T.; Nalini, N. The modulatory influence of p-methoxycinnamic acid, an active rice bran phenolic acid, against 1,2-dimethylhydrazine-induced lipid peroxidation, antioxidant status and aberrant crypt foci in rat colon carcinogenesis. Chem. Biol. Interact. 2012, 196, 11-22. [CrossRef]

15. Kumar, A. Phytochemistry, pharmacological activities and uses of traditional medicinal plant Kaempferia galanga L.-An overview. J. Ethnopharmacol. 2020, 253, 112667. [CrossRef]

16. Rook, M. p-Methoxycinnamate and Its Metabolite. J. Pharm. Sci. 1968, 57, 6-9.

17. Liu, B.; Liu, F.; Chen, C.; Gao, H. Supercritical carbon dioxide extraction of ethyl p-methoxycinnamate from Kaempferia galanga L. rhizome and its apoptotic induction in human HepG2 cells. Nat. Prod. Res. 2010, 24, 1927-1932. [CrossRef]

18. Eun, J.L.; So, R.K.; Kim, J.; Young, C.K. Hepatoprotective phenylpropanoids from Scrophularia buergeriana roots against CCl4-induced toxicity: Action mechanism and structure-activity relationship. Planta Med. 2002, 68, 407-411. [CrossRef]

19. Gunasekaran, S.; Venkatachalam, K.; Namasivayam, N. P-Methoxycinnamic acid, an active phenylpropanoid induces mitochondrial mediated apoptosis in HCT-116 human colon adenocarcinoma cell line. Environ. Toxicol. Pharmacol. 2015, 40, 966-974. [CrossRef]

20. Adisakwattana, S.; Hsu, W.H.; Yibchok-Anun, S. Mechanisms of p-Methoxycinnamic acid-induced increase in insulin secretion. Horm. Metab. Res. 2011, 43, 766-773. [CrossRef]

21. Ambika, S.; Saravanan, R.; Thirumavalavan, K. Antidiabetic and antihyperlipidemic effect of p-hydroxycinnamic acid on streptozotocin-induced diabetic Wistar rats. Biomed. Aging Pathol. 2013, 3, 253-257. [CrossRef]

22. Rijal, S.; Changdar, N.; Kinra, M.; Kumar, A.; Nampoothiri, M.; Arora, D.; Shenoy, R.R.; Ranganath Pai, K.S.; Joseph, A.; Mudgal, J. Neuromodulatory potential of phenylpropanoids; para-methoxycinnamic acid and ethyl-p-methoxycinnamate on aluminum-induced memory deficit in rats. Toxicol. Mech. Methods 2019, 29, 334-343. [CrossRef] [PubMed]

23. Santoso, B.S.A.; Khotib, J. Oil Fraction from Kaempferia galanga Alcoholic Extract Increases Apoptosis Activity in Mice Colon Cancer. In Proceedings of the Research and Application on Traditional Complementary and Alternative Medicine in Health Care (TCAM); Muhammadiyah University Press: Surakarta, Indonesia, 2012; pp. 66-72.

24. Omar, M.N.; Hasali, N.H.M.; Yarmo, M.A. Cytotoxicity activity of biotransformed ethyl p-methoxycinnamate by Aspergillus niger. Orient. J. Chem. 2016, 32, 2731-2734. [CrossRef]

25. Umar, M.I.; Iqbal, M.A.; Khadeer Ahamed, M.B.; Altaf, R.; Hassan, L.E.A.; Haque, R.A.; Abdul Majeed, A.M.S.; Asmawi, M.Z. Cytotoxic and Pro-Apoptotic Properties of Ethyl-p-Methoxycinnamate and Its Hydrophilic Derivative Potassium-p-Methoxycinnamate. Chem. Afr. 2018, 1, 87-95. [CrossRef]

26. Fennell, T.R.; Mathews, J.M.; Snyder, R.W.; Hong, Y.; Watson, S.L.; Black, S.R.; McIntyre, B.S.; Waidyanatha, S. Metabolism and disposition of 2-ethylhexyl-p-methoxycinnamate following oral gavage and dermal exposure in Harlan Sprague Dawley rats and B6C3F1/N mice and in hepatocytes in vitro. Xenobiotica 2018, 48, 1142-1156. [CrossRef]

27. Kusumawati, I.; Yusuf, H. Phospholipid Complex As a Carrier of Kaempferia Galanga Rhizome Extract To Improve Its Analgesic Activity. Int. J. Pharm. Pharm. Sci. 2011, 3, 1-3.

28. Zierenberg, O.; Grundf, S.M. Intestinal absorption of polyenephosphatidylcholine in man. J. Lipid Res. 1982, $23,1136-1142$.

29. Irby, D.; Du, C.; Li, F. Lipid-Drug Conjugate for Enhancing Drug Delivery. Mol. Pharm. 2017, 14, 1325-1338. [CrossRef]

30. Liu, H.; Bolleddula, J.; Nichols, A.; Tang, L.; Zhao, Z.; Prakash, C. Metabolism of bioconjugate therapeutics: Why, when, and how? Drug Metab. Rev. 2020, 52, 66-124. [CrossRef]

31. Jaeger, K.E.; Eggert, T. Lipases for biotechnology. Curr. Opin. Biotechnol. 2002, 13, 390-397. [CrossRef] 
32. Sakaki, K.; Aoyama, A.; Nakane, T.; Ikegami, T.; Negishi, H.; Watanabe, K.; Yanagishita, H. Enzymatic synthesis of sugar esters in organic solvent coupled with pervaporation. Desalination 2006, 193, 260-266. [CrossRef]

33. Clapés, P.; Infante, M.R. Amino acid-based surfactants: Enzymatic synthesis, properties and potential applications. Biocatal. Biotransformation 2002, 20, 215-233. [CrossRef]

34. Stamatis, H.; Sereti, V.; Kolisis, F.N. Enzymatic synthesis of hydrophilic and hydrophobic derivatives of natural phenolic acids in organic media. J. Mol. Catal. B Enzym. 2001, 11, 323-328. [CrossRef]

35. Lee, G.S.; Widjaja, A.; Ju, Y.H. Enzymatic synthesis of cinnamic acid derivatives. Biotechnol. Lett. 2006, 28, 581-585. [CrossRef]

36. Kumar, V.; Jahan, F.; Kameswaran, K.; Mahajan, R.V.; Saxena, R.K. Eco-friendly methodology for efficient synthesis and scale-up of 2-ethylhexyl-p-methoxycinnamate using Rhizopus oryzae lipase and its biological evaluation. J. Ind. Microbiol. Biotechnol. 2014, 41, 907-912. [CrossRef]

37. Vosmann, K.; Weitkamp, P.; Weber, N. Erratum: Solvent-free lipase-catalyzed preparation of long-chain alkyl phenylpropanoates and phenylpropyl alkanoates. J. Agric. Food Chem. 2006, 54, 3764. [CrossRef]

38. Sun, S.; Zhu, S.; Bi, Y. Solvent-free enzymatic synthesis of feruloylated structured lipids by the transesterification of ethyl ferulate with castor oil. Food Chem. 2014, 158, 292-295. [CrossRef]

39. Karboune, S.; St-Louis, R.; Kermasha, S. Enzymatic synthesis of structured phenolic lipids by acidolysis of flaxseed oil with selected phenolic acids. J. Mol. Catal. B Enzym. 2008, 52-53, 96-105. [CrossRef]

40. Safari, M.; Safari, M.; Karboune, S.; St-louis, R. Enzymatic synthesis of structured phenolic lipids by incorporation of selected phenolic acids into triolein. Biocatal. Biotransformation 2009, 2422, 272-279. [CrossRef]

41. Yang, H.; Mu, Y.; Chen, H.; Xiu, Z.; Yang, T. Enzymatic synthesis of feruloylated lysophospholipid in a selected organic solvent medium. Food Chem. 2013, 141, 3317-3322. [CrossRef]

42. Balakrishna, M.; Kaki, S.S.; Karuna, M.S.L.; Sarada, S.; Kumar, C.G.; Prasad, R.B.N. Synthesis and in vitro antioxidant and antimicrobial studies of novel structured phosphatidylcholines with phenolic acids. Food Chem. 2016, 221, 664-672. [CrossRef] [PubMed]

43. Czarnecka, M.; Switalska, M.; Wietrzyk, J.; Maciejewska, G.; Gliszczyńska, A. Synthesis and biological evaluation of phosphatidylcholines with cinnamic and 3-methoxycinnamic acids with potent antiproliferative activity. RSC Adv. 2018, 8, 35744-35752. [CrossRef]

44. Czarnecka, M.; Świtalska, M.; Wietrzyk, J.; Maciejewska, G.; Gliszczyńska, A. Synthesis, Characterization, and In Vitro Cancer Cell Growth Inhibition Evaluation of Novel Phosphatidylcholines with Anisic and Veratric Acids. Molecules 2018, 23, 2022. [CrossRef] [PubMed]

45. Rychlicka, M.; Maciejewska, G.; Niezgoda, N.; Gliszczyńska, A. Production of feruloylated lysophospholipids via a one-step enzymatic interesterification. Food Chem. 2020, 323, 126802. [CrossRef] [PubMed]

46. Rychlicka, M.; Niezgoda, N.; Gliszczyńska, A. Development and Optimization of Lipase-Catalyzed Synthesis of Phospholipids Containing 3,4-Dimethoxycinnamic Acid by Response Surface Methodology. Catalysts 2020, 10, 588. [CrossRef]

47. Okulus, M.; Gliszczy, A. Enzymatic Synthesis of O-Methylated Phenophospholipids by Lipase-Catalyzed Acidolysis of Egg-Yolk Phosphatidylcholine with Anisic and Veratric Acids. Catalysts 2020, 10, 538. [CrossRef]

48. Drzazga, A.; Okulus, M.; Rychlicka, M.; Biegała, Ł.; Gliszczyńska, A.; Gendaszewska-Darmach, E. Lysophosphatidylcholine Containing Anisic Acid Is Able to Stimulate Insulin Secretion Targeting G Protein Coupled Receptors. Nutrients 2020, 12, 1173. [CrossRef] [PubMed]

49. Rodrigues, R.C.; Virgen-ortíz, J.J.; José, C.S.; Berenguer-murcia, Á.; Alcantara, A.R.; Barbosa, O.; Ortiz, C.; Fernandez-lafuente, R. Immobilization of lipases on hydrophobic supports: Immobilization mechanism, advantages, problems, and solutions. Biotechnol. Adv. 2019, 37, 746-770. [CrossRef] [PubMed]

50. Compton, D.L.; Goodell, J.R.; Berhow, M.A.; Kenar, J.A.; Cermak, S.C.; Evans, K.O. Feruloylated Products from Coconut Oil and Shea Butter. JAOCS J. Am. Oil Chem. Soc. 2017, 94, 397-411. [CrossRef]

51. Laszlo, J.A.; Compton, D.L.; Eller, F.J.; Taylor, S.L.; Isbell, T.A. Packed-bed bioreactor synthesis of feruloylated monoacyl- and diacylglycerols: Clean production of a "green" sunscreen. Green Chem. 2003, 5, 382-386. [CrossRef]

52. Patil, D.; Dev, B.; Nag, A. Lipase-catalyzed synthesis of 4-methoxy cinnamoyl glycerol. J. Mol. Catal. B Enzym. 2011, 73, 5-8. [CrossRef] 
53. Ortiz, C.; Ferreira, M.L.; Barbosa, O.; Dos Santos, J.C.S.; Rodrigues, R.C.; Berenguer-Murcia, Á.; Briand, L.E.; Fernandez-Lafuente, R. Novozym 435: The "perfect" lipase immobilized biocatalyst? Catal. Sci. Technol. 2019, 9, 2380-2420. [CrossRef]

54. Zheng, Y.; Wu, X.M.; Branford-White, C.; Quan, J.; Zhu, L.M. Dual response surface-optimized process for feruloylated diacylglycerols by selective lipase-catalyzed transesterification in solvent free system. Bioresour. Technol. 2009, 100, 2896-2901. [CrossRef]

55. Manohar, B.; Divakar, S. Applications of surface plots and statistical designs to selected lipase catalysed esterification reactions. Process Biochem. 2004, 39, 847-853. [CrossRef]

56. Rychlicka, M.; Niezgoda, N.; Gliszczyńska, A. Lipase-Catalyzed Acidolysis of Egg-Yolk Phosphatidylcholine with Citronellic Acid. New Insight into Synthesis of Isoprenoid-Phospholipids. Molecules 2018, 23, 314. [CrossRef]

57. Li, N.G.; Shi, Z.H.; Tang, Y.P.; Li, B.Q.; Duan, J.A. Highly efficient esterification of ferulic acid under microwave irradiation. Molecules 2009, 14, 2118-2126. [CrossRef]

58. Stabile, R.G.; Dicks, A.P. Two-step semi-microscale preparation of a cinnamate ester sunscreen analog. J. Chem. Educ. 2004, 81, 1488-1491. [CrossRef]

Publisher's Note: MDPI stays neutral with regard to jurisdictional claims in published maps and institutional affiliations.

(C) 2020 by the authors. Licensee MDPI, Basel, Switzerland. This article is an open access article distributed under the terms and conditions of the Creative Commons Attribution (CC BY) license (http://creativecommons.org/licenses/by/4.0/). 